\title{
JOURNAL.RU
}

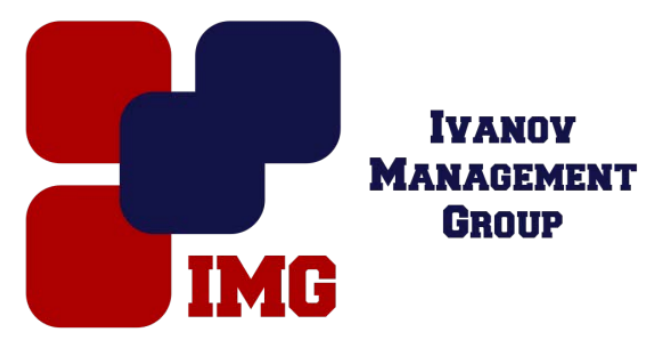

Василенко А.А., Абдуризаков Н.С., Пичхидзе С.Я. Модернизаиия эндопротеза голеностопного сустава Саратов, Россия

doi: 10.18411/lj-31-03-2017-2-08

idsp 000001:lj-31-03-2017-2-08

\section{Модернизация эндопротеза голеностопного сустава}

Известно, что эндопротезирование сустава - это операция по замене компонентов сустава имплантатами, имеющие анатомическую форму здорового сустава и позволяющие выполнять весь объём движений. Металлические эндопротезы изготавливают из нержавеющих стальных сплавов. Они фиксируются в костном ложе по посадке с натягом или посредством клеевого соединения, представляющего собой костную муку и акриловый полимер. Эти материалы должны обладать хорошей износостойкостью и легко поддаваться обработке, для достижения хорошего сопряжения компонентов протеза [1-3].

Известный сплав из смеси титана и золота может быть использован для изготовления надежных медицинских имплантатов. Материал показывает достаточно большую твердость среди всех титаново-золотых сплавов и соединений, а также в сравнении с титаном.

Новый сплав прочнее чистого титана, который является основным материалом для изготовления имплантатов. Конструкция прототипа приводит к металлозу и нестабильности эндопротеза.

Цель работы: модернизация конструкции эндопротеза голеностопного сустава.

Для изготовления верхней и нижней поверхностей эндопротеза ранее использовался титан. Нами предлагаются следующие изменения: 1) заменить титановые составные части имплантата на сплав золото-титан в пропорции 1:3; 2) выполнить ножку эндопротеза с наружной резьбой для достижения лучшего сопряжения с костной тканью. 
Преимущества разработанной конструкции перед прототипом состоят в повышении надежности за счет прочного биосовместимого сплава. При этом соответственно возрастает срок службы эндопротеза. Далее нами был проведен виртуальный анализ созданной модели, который позволил провести оценку напряженно-деформированного состояния составных элементов эндопротеза при нагрузке $250 \mathrm{H}$, рис.1. По результатам исследования выявлено наибольшее смещение, составляющее $1.3 * 10-4$ мм. Данное смещение примерно в 3 раза меньше максимального смещения при использовании титановых компонентов эндопротеза.

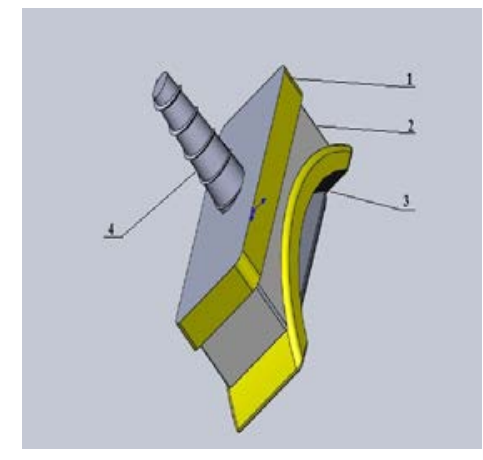

$a$

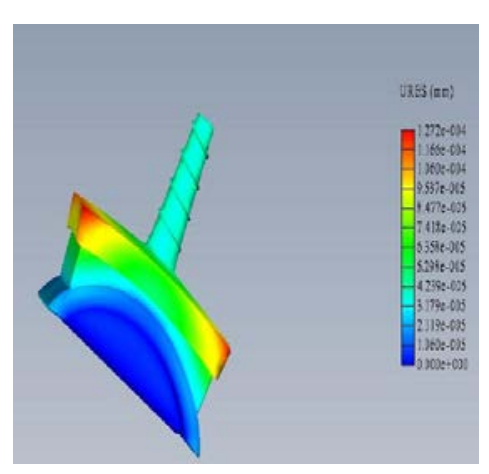

$\sigma$

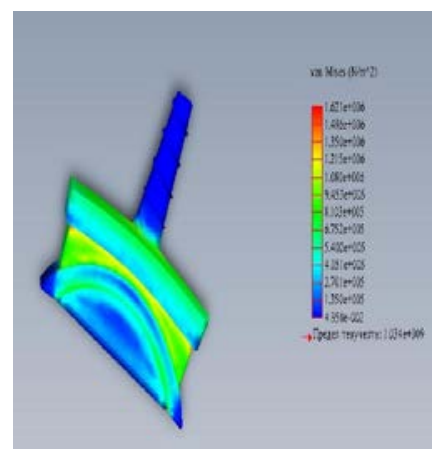

8

Рис.1.Энтропротез голеностопного сустава, где: а - общий вид, 1-верхняя поверхность; 2 - полиэтиленовый вкладыш; 3 - нижняя поверхность; 4 - ножка; 6 статические перемещения, мм; в - статический анализ узловых напряжений по Мизесу, Па

Выводы: усовершенствован эндопротез голеностопного сустава, предназначенный для замены поврежденного сустава искусственным аналогом. Сплав титан-золото делает конструкцию более прочной, тем самым увеличивая срок его службы. Добавление наружной резьбы на ножке верхней поверхности эндопротеза улучшает сопряжение с костной тканью.

\section{Литература}

1. Эндопротезирование суставов.- 2010. [Электронный pecypc]. URL: http://www.orthoscheb.com/Page.aspx?page=./28209/28223/29160.

2. Патент РФ № 2283069 от 10.04.2005. Голеностопный эндопротез / Кофед Хакон, Келлер Арнольд. - № 2283069, опубл. 10.06.2007.

3. Мельников В.В., Пичхидзе С.Я. Усовершенствование эндопротеза голеностопного сустава. Самара: Л-Журнал, 2016. - 3c. 